\title{
PENGEMBANGAN MANAJEMEN SEKOLAH TERINTEGRASI BERBASIS SISTEM INFORMASI DI SUMATERA UTARA
}

\author{
Fuji Rahmadi, Munisa, Salma Rozana, Charles Rangkuti, Rustam Ependi, Eko Harianto \\ Universitas Pembangunan Panca Budi \\ E-mail: fuji.rahmadi@gmail.com,munisa@pancabudi.ac.id, salmarozana18@dosen.pancabudi.ac.id, \\ charlesrangkuti30@gmail.com, rustamependi6@gmail.com, eko.hariyanto@dosen.pancabudi.ac.id
}

How to Cite:

Rahmadi. F., Munisa., Rozana. S., Rangkuti.C., Ependi. R., Harianto. E., (2021). Pengembangan Manajemen Sekolah Terintegrasi Berbasis Sistem Informasi di Sumatera Utara. Fitrab: Journal of Islamic Education, 2(1), 80-95.

\section{ARTICLE HISTORY}

Received : 29 November 2021

Revised : 01 December 2021

Accepted : 17 December 2021

Published : 18 December 2021

\section{KEYWORDS:}

School

Management Integration,

Information Systems

\section{ABSTRACT}

This study aims to analyze the application of an integrated information system in educational institutions, and the impact of the application of an education management information system on ethics and society. This research was conducted in three different locations, namely Medan City, Binjai City, and Asahan Regency. This research uses qualitative research methods, with data collection techniques using observation, interviews, and documentation studies. The results of the study explain that the application of an integrated information system developed by PT. Engineering Technology Metromatics uses the edulink application. This application is a school management-based application that can help educational institutions to create a learning environment and management activities to be more effective and efficient. By using this information system application, all data about the development of students will be recorded digitally, so that the actions that will be taken by teachers or parents/guardians of students in dealing with student problems can be about the substance of the problems faced by students. Through this information system, the track record of students will be clearly identified, so that actions in solving student problems can be carried out on target, effectively and efficiently. This application has a positive impact on teachers, especially in identifying and recording all attitudes and attitude assessments so that they can be the basis for developing student attitudes.

\section{RIWAYAT ARTIKEL}

Diterima : 29 November 2021 Direvisi : 01 Desember 2021 Disetujui : 17 Desember 2021 Diterbitkan : 18 Desember 2021

\section{KATA KUNCI:}

Manajemen Sekolah, Integrasi Manajemen, Sistem Informasi

\section{ABSTRAK}

Penelitian ini bertujuan untuk menganalisis penerapan sistem informasi terintegrasi pada lembaga pendidikan, dan dampak penerapan sistem informasi manajemen pendidikan terhadap etika dan sosial. Penelitian ini dilaksanakan di tiga lokasi berbeda yakni di Kota Medan, Kota Binjai, dan Kabupaten Asahan. Penelitian ini menggunakan metode penelitian kualitatif, dengan teknik pengumpulan data menggunakan teknik observasi, wawancara, dan studi dokumentasi. Hasil Penelitian menjelaskan bahwa penerapan sistem Informasi terintegrasi yang dikembangkan oleh PT. Metromatika Teknologi Rekayasa menggunakan aplikasi edulink. Aplikasi ini adalah aplikasi berbasis manajemen sekolah yang dapat membantu institusi pendidikan untuk menciptakan lingkungan didik dan kegiatan manajemen menjadi lebih efektif dan efesien. Dengan menggunakan aplikasi sistem informasi ini, data perkembangan peserta didik terekam secara digital, sehingga tindakan dilakukan oleh guru atau orang tua/wali peserta didik dalam menangani permasalahan peserta didik dapat mengenai substansi masalah yang dihadapi oleh peserta didik. Melalui sistem informasi ini, rekam jejak peserta didik akan teridentifikasi dengan jelas, sehingga tindakan dalam menyelesaikan masalah peserta didik dapat dilakukan dengan tepat sasaran, efektif dan efisien. Penerapan ini memberikan dampak positif terhadap guru, dalam mengidentifikasi seluruh sikap dan penilaian sikap sehigga dapat menjadi dasar dalam pengembangan sikap siswa. 


\section{PENDAHULUAN}

Sekolah adalah sebuah instansi pendidikan yang berfungsi untuk melakukan kegiatan belajar mengajar. Perkembangan teknologi informasi memang diakui begitu pesat, hampir dua tahun bahkan setahun sekali terjadi perubahan atau penambahan sistem dan teknologi informasi. Tujuan pendidikan yang efektif dan efisien adalah tujuan yang bersifat jelas, mengunakan bahasa-bahasa operasional agar mudah dipahami, penyusunan program harus menyeluruh dan saling bersinergi dengan program yang lain sehingga saling memberi manfaat yang positif. Manajemen sekolah merupakan faktor penting dalam melaksanakan suatu pendidikan dan pengajaran di sekolah dengan mengukur suatu keberhasilan dari prestasi yang diperoleh siswa. Sekolah sebagai organisasi dalam pengembangan dan pencapaian tujuan harus mengacu pada pedoman dan arah pengembangan pendidikan.

Dalam dunia pendidikan di sekolah saat ini penerapan sistem komputerisasi dan digitalisasi berperan dalam manajemen informasi di sekolah dengan persaingan bisnis yang terus berkembang. Tidak dapat dipungkiri bahwa peran teknologi dalam memberikan layanan informasi merupakan faktor penting bagi berbagai institusi dan individu.

Permasalahan saat ini masih banyak sekolah yang belum mengoptimalkan perkembangan teknologi, seperti masih banyaknya sistema pendaftaran yang dilakukan secara manual; memberikan laporan perkembangan peserta didik berkelanjutan secara manual; layanan konseling yang tidak efektif dikarenakan kondisi orang tua yang tidak bisa berpartisipasi. Inilah fenomena di beberapa sekolah yang ada di Medan, Binjai dan Deli Serdang, di mana terdapat banyak sekolah yang mengalami kendala di masa pandemi ini karena belum terakses sistem informasi yang baik.

Sistem informasi manajemen sekolah yang dapat diakses oleh semua orang melalui smart phone memberikan ide untuk membuat aplikasi sistem informasi manajemen sekolah yang dapat memberikan informasi tentang program kegiatan sekolah untuk guru, siswa dan orang tua siswa yang pada akhirnya sistem informasi manajemen tersebut dapat meningkatkan efektifitas dan efisiensi manajemen sekolah. Penyediaan sebuah situs diharapkan bisa membantu orang tua siswa mendapatkan informasi akademik dan perkembangan anaknya secara psikologis. Sehingga diharapkan tidak hanya untuk membantu memudahkan orang tua siswa tapi juga untuk meningkatkan kualitas sekolah itu sendiri. (Setyanto et al., 2018)

Orang tua akan lebih mudah dalam memantau perkembangan anak dan komunikasi dengan pihak sekolah melalui sistem informasi ini. Sistem informasi akan dirancang sesederhana mungkin sehingga memudahkan pengguna dan secara real time, artinya dapat diakses kapan saja dan terdapat notifikasi yang bisa langsung diketahui oleh 
pengguna. (Darwis \& Mahmud, 2017).

Perguruan tinggi memiliki peran untuk mendukung berjalannya aktifitas pendidikan di sekolah dengan memberikan kontribusi pemikiran terkait solusi terhadap problematika yang berkembang dalam manajemen sekolah. Salah satunya dengan mewujudkan sistem pengelolaan pendidikan yang berkemampuan sesuai tuntutan perkembangan dan revolusi teknologi informasi digital menuju era pendidikan 4.0 (cyber system). Dalam perjalanannya perguruan tinggi mengerahkan energi keilmuan yang dimiliki dengan melibatkan dosen, mahasiswa dan tenaga profesional seperti PT. Metromatika Teknologi Rekayasa.

Di lain sisi, manajemen informasi terintegrasi yang menggunakan sistem pesan direct message, akan membatasi penyebaran data peserta didik, baik yang positif maupun yang negatif. Dengan sistem pengelolaan data yang bersifat privat, data pelanggaran peserta didik akan terbatas aksesnya hanya dalam jangkauan orang tua peserta didik yang bersangkutan, dan tidak akan menyebar ke peserta didik atau orang tua yang lain. Dampak positif dari data pelanggaran peserta didik yang bersifat privat akan menjaga rasa percaya diri peserta didik yang melakukan pelanggaran dan juga akan menutup peluang bagi peserta didik yang lain untuk mencontoh atau melakukan pelanggaran yang sama. Dengan demikian, bukan hanya peningkatan mutu teknologi yang menjadi sasaran program ini di lembaga-lembaga pendidikan, tetapi juga peningkatan "mutu" psikologi untuk orang tua dan peserta didik.

Terdapat beberapa penelitian yang relevan dengan penelitian ini di antaranya Aplikasi sistem informasi manajemen sekolah terintegrasi dengan pendekatan Ratioal Unifed Process. (Hulu et al., 2020). Rancangan sistem Informasi berbasis Web Interaktif Terintegrasi. (Nurcahyanto, 2014). Perancangan sistem informasi akademik terintegrasi pada SLTP. (Raafi'udin \& Dewi, 2017). Sistem informasi terintegrasi di perguruan tinggi (Muslim, 2018). Peningkatan layanan prima melalui sistem informasi terintegrasi (Ulinafiah \& Wiyani, 2019). Integrasi informasi keuangan di lembaga pendidikan dengan tekonologi informasi (Fitriana et al., 2016). Sistem infomasi manajemen pendidikan (Simdik) dalam peningkatan mutu pendidikan. (Sonia, 2020). Dari beberapa penelitian tersebut tampak bahwa penelitiaan ini memiliki perbedaan khas, dimana penelitian ini cenderung pada sistem informasi yang menekankan pada identidikasi perilak dan sikap peserta didik, berbeda dengan sistem informasi yang lain yang cenderung pada manajemen administrasi saja.

Penelitian ini tentunya memiliki kontribusi yang signifikan bagi pengembangan teknologi pendidikan, khususnya dalam mempermudah untuk mengidentifikasi ragam sikap siswa, sehingga dari kasus-kasus sikap yang ada dapat menjadi dasar dalam perbaikan atau pun penentuan kebijakan pendidikan. Terutama yang berkaitan dengan pendidikan afektif. Secara 
khusus penelitian ini bertujuan untuk menganalisis penerapan sistem informasi terintegrasi pada lembaga pendidikan, dan dampak penerapan sistem informasi manajemen pendidikan terhadap etika dan sosial.

\section{KAJIAN TEORI}

Pada dasarnya semua aktivitas manusia membutuhkan manajemen, tujuannya ialah untuk memudahkan manusia dalam menjalankan dan mencapai tujuan dari aktivitas tersebut, termasuklah aktivitas pendidikan. Saat ini di era Modern sangat dituntut kecanggihan teknologi, bahkan dalam me-manage yang seyogyanya dilakukan sepenuhnya oleh manusia, saat ini terbantu dengan adanya kecanggihan teknologi. Sistem informasi berbasis digital misalnya, mampu untuk mendokumentasikan informasi, menyimpan informasi, bahkan mengorganisir informasi, untuk kemudian dianalisis dan dikemas menjadi bahan atau data yang dapat dipergunakan. (Kuntoro, 2019).

Sistem informasi manajemen merupakan sebuah bidang yang mulai berkembang sejak tahun 1960-an. Secara umum sistem informasi manajemen didefinisikan sebagai sistem yang menyediakan informasi yang digunakan untuk mendukung operasi, manajemen, serta pengambilan keputusan sebuah organisasi. Sistem informasi manajemen menggambarkan suatu unit atau badan khusus yang bertugas untuk mengumpulkan berita dan memprosesnya menjadi informasi untuk keperluan manajerial organisasi dengan memakai prinsip sistem, karena berita yang tersebar dalam berbagai bentuknya dikumpulkan, disimpan serta diolah dan diproses oleh satu badan yang dirumuskan menjadi suatu informasi.(Rusdiana \& Irfan, 2014).

Kata sistem berasal dari bahasa Yunani, yaitu systema, yang artinya himpunan bagian atau komponen yang saling berhubungan secara teratur dan merupakan suatu keseluruhan. Selain itu, bisa diartikan sekelompok elemen yang independen, namun saling terkait sebagai satu kesatuan. Sistem terdiri atas struktur dan proses. Struktur sistem merupakan unsur-unsur yang membentuk sistem tersebut, sedangkan proses sistem menjelaskan cara kerja setiap unsur sistem dalam mencapai tujuan. (Wardhani \& Aziz, 2018). Sedangkan Informasi atau dalam bahasa Inggrisnya adalah information, berasal darikata informacion bahasa Prancis. Kata tersebut diambil dari bahasa Latin, yaitu informationem yang artinya konsep, ide, garis besar. Informasi adalah suatu data yang sudah diolah atau diproses sehingga menjadi suatu bentuk yang memiliki arti bagi penerima informasi yang memiliki nilai bermanfaat. Informasi merupakan sesuatu yang dihasilkan dari pengolahan data. Data yang sudah ada dikemas dan diolah sedemikian rupa sehingga menjadi sebuah informasi yang berguna. (Lukman \& Munawir, 2018)

Sistem merupakan satu kesatuan yang saling terkait. Informasi adalah data yang telah dikelola menjadi sebuah bentuk yang dapat diterima penerima sebagai pengetahuan. 
Manajemen adalah serangkaian kegiatan dimulai dari perencanaan hingga evaluasi juga tindak lanjut yang dilakukan oleh dua orang atau lebih untuk mencapai tujuan yang telah ditetapkan sebelumnya secara efektif dan efisien.(Khadijah, 2015).

Tujuan sistem informasi manajemen ialah menciptakan kelancaran sumber informasi di lembaga terkait, lebih mudah dalam pengolahan data dan mendapati data pada sistem organisasi atau lembaga terkait, mengontrol kualitas guna peningkatan mutu lembaga terkait. Sistem informasi manajemen pendidikan memiliki tujun menghasilkan informasi yang tepat waktu (timely) bagi manajemen tentang lingkungan eksternal dan operasi internal, mendorong dan mempercepat proses pengambilan keputusan baik pada saat perencanaan, pengorganisasian, penggerakkan, dan pengendalian. Beberapa fungsi sistem informasi manajemen antara lain, (a) mendukung pengambilan keputusan para pegawai dan manajernya. (b) mendukung proses operasi organisasi, dan mendukung berbagai strategi untuk keunggulan kompetitif, seperti mengaitkan fungsi manajemen.(Alenezi et al., 2018).

Dalam era teknologi saat ini, perusahaan atau organisasi dituntut untuk mengikuti perubahan terutama dalam bidang sistem informasi. Penggunaan sistem informasi tidak melihat dari besar atau kecilnya sebuah organisasi. Fenomena tersebut dapat dilihat bahwa hampir semua organisasi dalam pengelolaannya telah terkomputerisasi. Penggunaan sistem informasi yang tepat tidak hanya berlaku pada perusahaan atau organisasi komersial saja tetapi juga berlaku pada organisasi pendidikan. Seiring berkembangnya sistem informasi, organisasi pendidikan pun juga berusaha menerapkan sistem informasi dalam segala bagian. Dengan adanya sistem informasi pada organisasi pendidikan diharapkan kegiatan belajar mengajar maupun kegiatan administrasi lebih efektif dan efisien. Peranan sistem informasi tidak hanya untuk efisiensi dan efektifitas, tetapi sudah untuk strategik, yaitu untuk memenangkan persaingan. Sistem Informasi sekarang juga disebut sebagai senjata strategik (strategic weapon) atau senjata kompetitif (competitive weapon), yaitu mampu digunakan sebagai alat ampuh untuk berkompetisi. Sistem informasi dalam organisasi juga digunakan untuk mempertahankan posisi organisasi dan meningkatkan keunggulan kompetitif.

Penggunaan sistem atau teknologi informasi dapat dijadikan sebagai salah satu komponen peningkatan mutu di sekolah. Hal ini terkait pada peningkatan kualitas akademik sebuah strategi unggul untuk mencapai keunggulan kompetitif sehingga sekolah dapat bersaing dengan sekolah yang lain dalam kancah pendidikan diera global.

Kesuksesan sistem informasi merupakan suatu tingkat di mana sistem informasi mampu memberikan konstribusi pada organisasi dalam pencapaian tujuannya. Sebaliknya dikatakan 
gagal apabila sistem tersebut kurang atau bahkan tidak dimanfaatkan oleh penggunanya. Agar suatu sistem informasi dapat beroperasi secara optimal, perlu adanya evaluasi terhadap sistem informasi. (Indrayani, 2018). Karena biaya yang dikeluarkan untuk menerapkan sistem informasi yang berbasis teknologi informasi tidak sedikit. Kepuasan pengguna adalah salah satu bentuk evaluasi terhadap sistem informasi. (Aminuddin et al., 2021).

\section{METODE PENELITIAN}

Metode yang digunakan dalam penelitian ini adalah metode kualitatif. Penggunaan metode ini bertujuan untuk menggambarkan secara utuh tentang penerapan manajemen terintegrasi berbasis sistem informasi. Penelitian ini dilaksanakan di beberapa sekolah yang tersebar di 3 kabupaten/kota Sumatera Utara, yaki Kota Medan, Kota Binjai, Kabupaten Asahan, yakni: SMK Yayasan Putra Anda Sumatera Utara Kota Binjai, SMA Negeri 1 Kota Binjai, SD, SMP, SMA IT Yayasan Al fityah Kota Binjai, MAS Al Washliyah Muallimin Medan, SMA Negeri 6 Medan, Madrasah Aliyah dan MTs Islamic Center Sumatera Utara, SD dan SMP IT Al Hijrah, SMA, SMP dan SMK Panca Budi, MAS Al Washliyah Pasar Lembu, MTs Al Washliyah Kisaran kabupaten Asahan. Penelitian ini dilaksanakan kurang lebih selama enam bulan mulai dari bulan Juli hingga Desember 2021.

Pengumpulan data menggunakan teknik observasi, wawancara, dan studi dokumentasi. Teknik Observasi dilakukan untuk mengamati seluruh aktivitas manajemen terintegrasi berbasis
Sistem informasi. Pengamatan tidak hanya pada sistemnya akan tetapi pada penerapan guru menggunakan aplikasi edulink. Wawancara dilakukan untuk mengetahui manfaat ataupun kendala yang mungkin dihadapi dalam penerapan sistem ifnformasi tersebut. Sedangkan dokumentasi dilakukan pada rekam jejak informasi yang terdapat di aplikasi Edulink, dengannya akan diperoleh data yang berkaitan dengan manajeme integrasi berbasis sistem informasi. Analisis data dilakukan dengan melalui tahapan redukasi data, penampilan data, dan penarikan simpulan. Untuk menjami keabsahan data dilakukan member crosscheck, dan trianggulasi data. Untuk jelasnya alur penelitian seperti yang tertera pada tabel berikut:

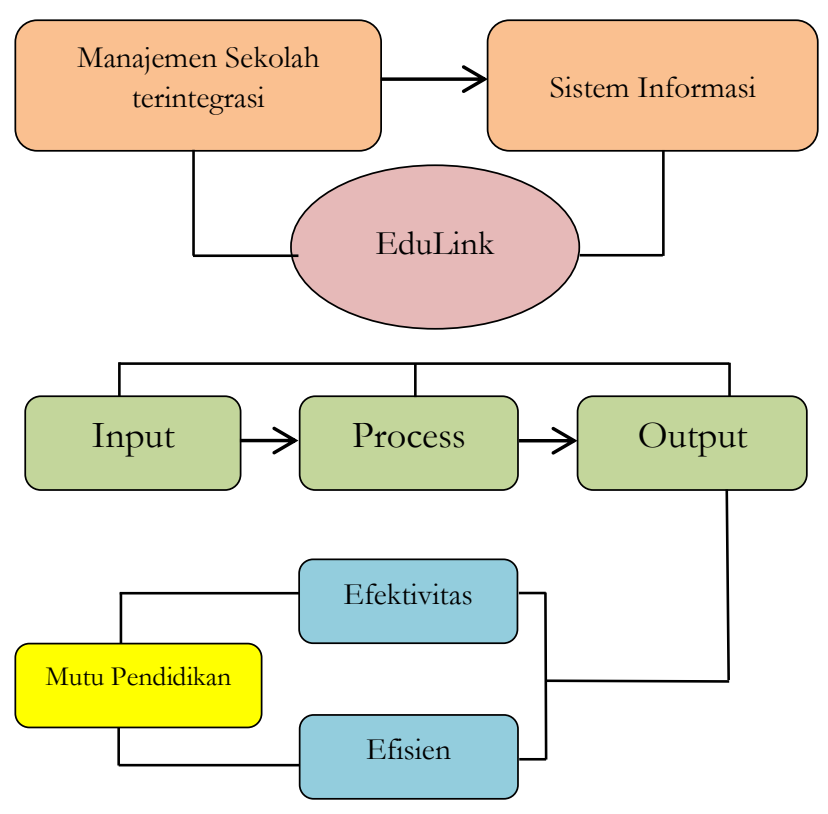

Bagan 1. Alur Penelitian

\section{HASIL DAN PEMBAHASAN PENELITIAN}

Sebagaimana yang telah disebutkan sebelumnya bahwa penelitian ini akan mengkaji dua hal yakni menganalisis penerapan sistem informasi terintegrasi pada lembaga pendidikan, 
dan dampak penerapan sistem informasi manajemen pendidikan terhadap etika dan sosial.

\section{Penerapan Sistem Informasi Terintegrasi untuk Lembaga Pendidikan}

Sistem terintegrasi yang akan dibangun di sekolah bernama Edulink. Edulink adalah sistem informasi pembelajaran berbasis web yang dirancang khusus untuk para siswa/i dan guru di sekolah yang ditujukan untuk menunjang proses belajar mengajar. Sistem ini nantinya akan membantu para guru untuk memudahkan berbagai kegiatan akademis siswa yang biasanya dilakukan langsung di sekolah, seperti berbagi materi pelajaran, memberi tugas dan berkirim pesan antar guru-siswa Sistem ini diterapkan untuk Admin, Guru, dan Siswa. Gambaran karateristik ketiga pengguna dijelaskan sebagai berikut:

a. Admin bertanggung jawab dalam mengelola seluruh data siswa, guru, dan pelajaran di sekolah. Pihak Admin sebagai superuser memiliki kendali penuh atas sistem. Semua data yang hendak dimasukkan dalam sistem haruslah terverifikasi oleh Admin. Pihak Admin itu sendiri dimiliki oleh koordinator di tugas kepala sekolah

b. Guru sebagai tenaga pendidik dalam sekolah, bertanggung jawab dalam menyalurkan materi bahan ajar sesuai dengan jenjang pendidikan dan siswa didik guru yang bersangkutan. Setiap Guru yang hendak menggunakan sistem haruslah berstatus aktif dan data telah terverifikasi oleh admin.

c. Bertanggung jawab dalam mengikuti proses pembelajaran yang telah dimuat oleh guru dalam sistem. Setiap Siswa yang hendak menggunakan sistem juga haruslah berstatus aktif dan data yang dimiliki telah terverifikasi oleh Admin.

Sistem informasi Edulink menjadi Sistem Informasi Manajemen Sekolah yang mencakup Akademik, PPDB, pembelajaran daring, ujian online, PPDB, keuangan sekolah, hingga layanan informasi terhadap wali murid. Kepala Sekolah memandang Sidikmu adalah sebuah media, media yang harus dimanfaadkan sebaik mungkin, jika sumber daya manusianya tidak mampu menggunakan media tersebut maka akan sia - sia. Kepala Sekolah yang berperan sebagai manager dari lemabaga pendidikan yang memiliki tugas diantaranya, Planing, Organizing, Actualing dan Evaluating yang diwujudkan dalam kebijakan serta program-program yang dibuat. Dalam hal ini Kepala Sekolah dalam upaya menjalankan Sidikmu telah membuat beberapa program baik untuk admin sekolah, guru, maupun wali murid.

Seiring dengan perkembangan zaman dan majunya peradaban dunia dan dinamika kehidupan penduduk bumi yang tidak jarang menyebabkan gejolak kehidupan sosial. Dan dimana permasalahan sosial selalu timbul setiap saat dikarenakan sangat cepatnya arus globalisasi yang terjadi ini. Sarlito W. Sarwono menyatakan bahwa maju dan berkembangnya peradaban 
dunia juga mempengaruhi alatpendukungnya, diantaranya adalah teknologi komunikasi yang penggunaannya sebagai alat bantu untuk memproses dan menstranfer perangkat data informasi yang dibutuhkan, teknologi komunikasi pula sebagai sebab masuknya norma dan nilai baru dari luar yang pada gilirannya norma dan nilai baru ini masuk kedalam lingkungan kehidupan keluarga dan masyarakat.

Sistem informasi manajemen merupakan suatu sistem operasional yang melaksanakan atau menjalankan beraneka ragam fungsi untuk menghasilkan luaran yang berguna bagi pelaksanaan operasi dan manajemen organisasi yang bersangkutan. Penerapan sistem informasi manajemen pada kehidupan sehari-hari sangat banyak ditemukan. Dalam dunia pendidikan sistem informasi manajemen pendidikan pun serta teknologi informasi sangatlah mendukung untuk meningkatkan kualitas pembelajaran. (Joko, 2021).

\section{Penerapapan atau implementasi} pendidikan dimas mendatang akan mengalami perubahan yang secara mendasar, khususnya yang disebabkan oleh aplikasi teknologi informasi yang mempercepat transfer ilmu pengetahuan. Jenis teknologi yang secara langsung berpengaruh kuat pada pelaksanaan pendidikan adalah komputer, jaringan internet yang dapat dikonstruksi untuk suatu proses pembelajaran. Didunia pendidikan, banyak sekali lembaga pendidikan yang berhasil mengembangkan teknologi informasi dalam mendukung proses pembelajarannya, baik didalam maupun diluar negeri sehingga dapat mengadopsi pola pembelajaran yang lebih mudah, cepat, memiliki nilai tambah serta inovatif dalam mencari formalasi baru untuk memberikan tambahan ilmu dan pengetahuan maupun keteampilan bagi peserta didiknya. Sekolah yang melakukan pelayanan terhadap siswa merupakan institusi yang sangat membutuhkan kehadiran teknologi informasi sebagai pendukung peningkatan kualitas pelayanan.(Mesiono \& Haidir, 2021).

Sistem informasi manajemen sekolah dapat dikatakan berjalan apabila semua komponen sekolah dapat menggunakan dan memanfaatkan sistem itu sendiri, sebagai contoh adanya fasilitas terpadu atau terintegrasi jadi satu mulai dari database peserta didik, guru, bimbingan dan konseling, kartu pelajar yang ada barcodenya, daftar hadir siswa, guru ataupun pegawai, nilai (ulangan, UTS,UAS, Try out dll) dimana rapor otomatis diprogram. Dan juga dalam sekolah itu juga terdapat aplikasi SMS gateway sistem atau biasa disebut sms smart school ini juga mudah karena dikelola sendiri oleh sekolah jadi biaya akses lebih murah dan mudah dipantau. Dengan SMS smart school wali siswa dapat menerima laporan otomatis dari pihak sekolah, misalnya nilai siswa, pelanggaran disiplin, pembayaran uang sekolah, data guru dan informasi sekolah transparan lainnya. (Idris et al., 2021).

Sistem Informasi informasi terintegrasi ialah segala macam hasil interaksi antara elemen 
di lingkungan akademik untuk menghasilkan informasi yang dijadikan landasan pengambilan keputusan, melaksanakan tindakan, baik oleh pelaku proses itu sendiri ataupun dari pihak luar sekolah. Implementasi sistem informasi manajemen akademik di tingkat SMA/SMK/MA memiliki kelengkapan manajemen data seperti: manajemen tahun ajaran, data jenis pelanggaran siswa di sekolah, data ekstrakurikuler, data mata pelajaran, data jurusan, data guru, data siswa, data kelas atau rombongan belajar, data nilai ekstrakurikuler, data pelanggaran siswa, data absensi siswa dan data absensi guru.

Pemanfaatan sistem informasi manajemen khususnya dalam bidang pendidikan sudah sangat diperlukan dalam pengelolaan, baik dalam hal pengelolaan administrasi akademik, administrasi pelaporan dan kepegawaian dan masih banyak lagi bidang-bidangnya yang lain yang membutuhkan layanan sistem informasi manajemen pendidikan ini. Kebutuhan akan aplikasi database yang dapat mengelola data dan informasi sekolah, manajemen sekolah dan komite-komite pembelajaran, juga menyangkut kebutuhan untuk menjadikan laporan-laporan dari sekolah secara cepat dan valid kepada instansi terkait seperti laporan ke dinas pendidikan kabupaten atau kota, provinsi maupun kementrian pendidikan nasional. Teknologi informasi juga merupakan salah satu senjata pesaing. Hal ini dapat terlihat bahwa teknologi informasi menjadi salah satu alat untuk meningkatkan efesiensi dalam aktivitas operasional lembaga pendidikan, bahkan untuk menjadi pilihan masyarakat saat ini, lembaga pendidikan harus memiliki seperangkat teknologi nformasi yang memadai. (Husaini, 2017).

Untuk melihat sampai sejauh mana proses implementasi Pengelolaan sistem informasi manajemen pendidikan, sebagai kepala sekolah mempunyai beberapa kriteria dalam menjalankan sistem informasi manajemen pendidikan antara lain sebagai berikut :

a. Dapat menentukan pendekatan yang tepat dalam merencanakan sistem Informasi manajemen pendidikan di sekolahnya.

b. Penerapan sistem informasi manajemen pendidikan secara efektif dan efisien oleh kepala sekolah ditunjukkan dengan kemampuan: mengumpulkan data secara komprehensif sesuai dengan kebutuhan, mampu mengolah data dengan menjadi informasi yang tepat, mampu menggunakan sistem informasi manajemen pendidikan sebagai hasil olahan dalam mengambil keputusan.

Dalam pelaksanaan administrasi sistem informasi digunakan beberapa Macam administrasi yaitu administrasi ketatausahaan, administrasi guru dan pengajaran. Pengelolaan dan pelaksanaan SIMDIK telah banyak membantu, memperlancar dan mempermudah 
pelaksanaan administrasi ketatausahaan di sekolah. Hal ini disebabkan karena segala informasi maupun data yang menyangkut administrasi sekolah telah tersimpan sehingga dapat memperlancar kegiatan akademik, tersedianya informasi yang dibutuhkan, secara cepat dan tepat, pekerjaan akan lebih efektif dan efisien.

Kriteria atau ukuran keberhasilan manjemen pendidikan adalah produktivitas pendidikan, yang dapat dilihat pada produk, hasil atau efektivitas dan pada proses, suasana atau efisiensi. Kriteria keberhasilan memerlukan proses manajemen pendidikan, minimal meliputi perilaku manusia dalam berorganisasi. Perilaku manusia dalam berorganisasi dapat dinyatakan dalam bentuk perencanaan, pelaksanaan, pengawasan atau pengendalian termasuk memimpin. (Baharun, 2016). Organisasi yang menjadi tempat untuk membina dan mengembangkan karir-karir sumber daya manusia, memerlukan manajer yang mampu merencanakan, melaksanakan, memimpin dan mengendalikan agar organisasi dapat mencapai tujuan yang telah ditetapkan. Ada tiga hal penting yang perlu dicermati dari definisi tersebut antara lain proses, pendayagunaan seluruh sumber organisasi dan pencapaian tujuan organisasi yang telah ditetapkan.

Dalam manajemen pendidikan, pengarahan ini bersifat sangat kompleks karena disamping menyangkut manusia juga menyangkut berbagai tingkah laku dari manusia manusia itu sendiri. Manusia dengan berbagai tingkah laku yang berbeda-beda, memiliki pandangan serta pola hidup yang berbeda pula. Oleh karena itu, pengarahan yang dilakukan oleh pimpinan harus berpegang beberapa prinsip, yaitu : (a) Prinsip pengarahan pada tujuan, (b) Prinsip keharmonisan dengan tujuan, (c) Prinsip kesatuan komando.

Pendelegasian wewenang bersifat lebih umum. Pemimipin melimpahkan sebagian dari wewenang yang di milikinya kepada bawahan melalui Job Discription (jabaran tugas) pada masing-masing personil. Secara praktis fungsi Actuating ini merupakan usaha untuk menciptakan iklim kerjasama diantara staf pelaksana program sehingga tujuan organisasi dapat tercapai secara efektif dan efisien. Fungsi actuating tidak terlepas dari fungsi manajemen melalui penentuan masalah, penetapan tujuan, penetapan tugas dan sumber daya penunjang, menggerakkan dan mengarahkan, memiliki keberhasilan sumber daya manusia.

\section{Dampak Penerapan Sistem Informasi Manajemen Pendidikan Terha dap Etika dan Sosial}

Menurut Eti Rochaety dampak positif diterapkannya teknologi informasi pada organisasi pendidikan adalah kinerja organisasi lebih efisien karena teknologi informasi dapat menghapus posisi penyambung komunikasi dari dua tempat yang berkepentingan, juga menghapuskan batas waktu untuk operasi internasional. Selain itu peserta didik atau mahasiswa bisa melaksanakan pembelajaran 
dengan berbasis internet yang biasa disebut dengan e-learning sehingga pembelajarannya lebih praktis dan hasil atau mutu dari pembelajarannya yang lebih praktis dan hasil atau mutu dari pembelajarannya tidak kalah bagus dengan pembelajaran klasikal.

Dalam penerapannya teknologi informasi menjadi penghubung antara perusahaan dengan pelanggan, lihat saja internet banking, mobile banking, home shopping, e-consultancy, e-commerce, dsb. Dimana menurut bahwa gelombang teknologi informasi yang berbasis internet berkembang melalui tahapan sebagai berikut:

a. Gelombang pertama, pemanfaatan TI difokuskan untuk meningkatkan produktivitas dan memperkecil biaya

b. Gelombang kedua, TI difokuskan untuk meningkatkan efektifitas penggunaan peralatan komputer melalui pembangunan jaringan computer

c. Gelombang ketiga, TI difokuskan untuk menghasilkan keuntungan melalui pembangunan program sistem informasi

d. Gelombang keempat, TI difokuskan untuk membantu proses pengambilan keputusan dari data kualitatif

e. Gelombang kelima, TI difokuskan untuk meraih pelanggan (konsumen) melalui pengembangan jaringan internet

f. Gelombang keenam, TI mengembangkan sistem jaringan tanpa kabel (Wireless). Sistem tersebut dapat memungkinkan seseorang mengakses internet melalui komputer yang terhubung ketelepon seluler. (Cholik, 2017).

Namun secara umum perkembangan teknologi informasi ini mengganggu hak privasi individu, bahwa banyak sekarang penggunaan komputer sudah diluar etika penggunaannya misalnnya, pemanfaatan teknologi komputer dengan mudah dapat mengakses data dan informasi dengan cara yang tidak sah, belum lagi ada sebagian orang yang memanfaatkan komputer dan internet untuk mengganggu orang lain dengan tujuan sekedar untuk kesenangan atau hobi, ada pula yang memanfaatkan teknologi komputer ini untuk melakukan tindakan kriminal atau sesuatu yang dapat mengancam keselamatan penggunya. Bukan suatu hal yang baru bila kita dapat mengamati bahwa dengan kemajuan teknologi yang semakin meningkat pula tindak kejahatan yang dapat terlihat seperti adanya penayangan tindak kejahatan diinternet membuat orang dapat mencontohnya ataupun penipuan-penipuan yang dilakukan. (Islamy et al., 2018).

Dapat disimpulkan bahwa teknologi dan informasi yang berkembang cepat dengan sistem di era modern ini membawa dua dampak yaitu positif dan dampak negatif, namun, terlepas dari dampak tersebut, terlihat bahwa berbagai organisasi khususnya organisasi pendidikan menyambut dengan baik perkembangan teknologi informasi. Hal ini dapat dilihat dengan banyaknya sekolah ataupun universitas yang menerapkan teknologi informasi. Dan pihak 
sekolah sendiri harus mempersiapkan strategi untuk menghadapi dampak negatif atau permasalahan yang mungkin terjadi dari penerapan teknologi informasi tersebut. Dan salah satu cara yang dapat dilakukan yaitu memadukan antara teknologi informasi dengan sumber daya manusia agar tidak terjadinya peningkatan pengangguran.Selain hal diatas dalam kecepatan penyajian informasi berakibat penerapan teknologi informasi tersebut akan memberikan kesempatan kepada guru dan pengurus sekolah untuk meningkatkan kualitas komunikasi dan pembinaan kepada siswa. Dengan hal itu dapat membuat siswa akan merasa lebih dimanusiakan dalam upaya mengembangkan kepribadian dan pengetahuannya.

\section{SIMPULAN}

Berdasarkan penjelasan di atas dapat diambil simpula bahwa untuk menerapkan sistem informasi manajemen pendidikan yang terpadu dalam mendukung keberhasilan dunia pendidikan yang signifikan, diperlukan keseimbangan sumber daya yang tersedia antara ketersediaan sumber daya manusia yang memiliki keterampilan dalam mengoperasikan teknologi seperti komputer dan ketersediaan dana untuk pengadaan perangkat komputer yang sudah semakin canggih. Oleh karena itu, dalam penerapan manajemen sekolah terintegrasi berbasis sistem informasi yang memiliki nilai tambah, betul-betul memiliki persiapan yang sangat matang sehingga harapan untuk mengaplikasikan dapat terwujud sesuai dengan perkembangan dunia pendidikan yang dituntut di zaman modern ini.

\section{DAFTAR PUSTAKA}

Alenezi, A., Emmanouilidis, C., \& Al-Ashaab, A. (2018). Knowledge Management to Support Learning Analytics in Higher Eduction. 2018 IEEE 5th International Congress on Information Science and Technology (CiSt), 362-367. https://doi.org/10.1109/CIST.2018.85966 53

Aminuddin, A., Harahap, A. S., \& Dawi, M. N. (2021). Sistem Finansial Pendidikan di Indonesia (Analisis Tentang Signifikansinya Terhadap Pengelolaan Human Capital). Hikmah, 18(2), 119-130. https://doi.org/10.53802/hikmah.v18i2.12 5

Baharun, H. (2016). Manajemen Kinerja dalam meningkatkan Competitive Advantage pada Lembaga Pendidikan Islam. At-Tajdid: Jurnal Ilmu Tarbiyah, 5(2), 243-262. http://ejournal.inismupacitan.ac.id/index.p $\mathrm{hp} /$ tajdid/article/view/21

Cholik, C. A. (2017). Pemanfaatan Teknologi Informasi dan Komunikasi untuk Meningkatkan Pendidikan di Indonesia. Syntax Literate; Jurnal Ilmiah Indonesia, 2(6), 21-30.

https://www.jurnal.syntaxliterate.co.id/ind ex.php/syntax-literate/article/view/130

Darwis, A., \& Mahmud, H. (2017). Sistem Informasi Manajemen pada Lembaga Pendidikan Islam. Kelola: Journal of Islamic Education Management, 2(1), 15-19. https://doi.org/10.24256/kelola.v2i1.444

Fitriana, D., Yusuf, M., \& Susanti, E. (2016). Pengembangan Lembar Kerja Siswa Menggunakan Pendekatan Saintifik untuk Melihat Berpikir Kritis Siswa Materi Perbandingan. Jurnal Pendidikan Matematika Sriwijaya, 10(2), 23-38. 
Hulu, Y., Simbolon, N., Venta Br.Tarigan, E., Bunawolo, M., \& Turnip, M. (2020). Aplikasi Sistem Informasi Manajemen Sekolah Terintegrasi dengan Pendekatan Rational Unified Process. Jurnal Ilmu Komputer dan Sistem Informasi (IIKOMSI), 3(1), 11-17. https://doi.org/10.9767/jikomsi.v3i1.77

Husaini, M. (2017). Pemanfaatan Teknologi Informasi dalam Bidang Pendidikan (eeducation). Mikrotik: Jurnal Manajemen Informatika, 2(1), 80-90. https://ojs.ummetro.ac.id/index.php/mikr otik/article/view/314

Idris, S., Rambe, D., Afriani, D., \& Hastuti, H. (2021). Manajemen Kolaborasi dalam Meningkatkan Mutu Pendidikan Masyarakat (Studi Deskriptif pada Organisasi Ikatan Keluarga Besar Baringin Sip). Hikmah, 18(1), 1-12. https://doi.org/10.53802/hikmah.v18i1.10 0

Indrayani, E. (2018). Pengelolaan Sistem Informasi Akademik Perguruan Tinggi Berbasis Teknologi Informasi dan Komunikasi (TIK). Jurnal Penelitian Pendidikan, 12(1), 151-160. http://jurnal.upi.edu/file/5.pdf

Islamy, I. T., Agatha, S. T., Ameron, R., Fuad, B. H., Evan, E., \& Rakhmawati, N. A. (2018). Pentingnya Memahami Penerapan Privasi di Era Teknologi Informasi. Jurnal Teknologi Informasi dan Pendidikan, 11(2), 21-28. https://doi.org/10.24036/tip.v11i2.137

Joko, B. S. (2021). Sistem Informasi Manajemen Perguruan Tinggi dalam Bidang Pendataan Pendidikan Tinggi. Jurnal Pendidikan Dan Kebudayaan, 16(2), 146-156. https://dx.doi.org/10.24832/jpnk.v16i2.44 2

Khadijah, I. (2015). Manajemen Mutu Terpadu (TQM) pada Lembaga Pendidikan Islam. Al-Idarah: Jurnal Kependidikan Islam, 5(1). https://doi.org/10.24042/alidarah.v5i1.75 4

Kuntoro, A. T. (2019). Manajemen Mutu
Pendidikan Islam. Jurnal Kependidikan, 7(1), 84-97.

https://doi.org/10.24090/jk.v7i1.2928

Lukman, A., \& Munawir. (2018). Sistem Informasi Manajemen. Lembaga Kita.

Mesiono, M., \& Haidir, H. (2021). Manajemen Pembiayaan Pendidikan (Analisis Konsep dan Implikasinya Terhadap Peningkatan Mutu Pendidikan). Hikmah, 17(2), 61-73. https://doi.org/10.53802/hikmah.v17i2.88

Muslim, B. (2018). Analisis Sistem Informasi (SI) Terintegrasi di Perguruan Tinggi (PT)(Studi Kasus: STT Pagar Alam). Jurnal Teknologi Informasi MURA, 10(2), 83-91. https://doi.org/10.32767/jti.v10i2.375

Nurcahyanto, I. E. (2014). Perancangan Sistem Informasi Manajemen Sekolah Berbasis WEB Interaktif Terintegrasi di SMK Negeri 1 Nabire (pp. 34-35). ITN malang. http://eprints.itn.ac.id/278/

Raafi'udin, R., \& Dewi, C. N. P. (2017). Analisa dan Perancangan Sistem Informasi Akademik Terintegrasi pada Sekolah Menengah Tingkat Pertama. Jurnal TI Atma Lubur, 4(1), 94-102. http://jurnal.atmaluhur.ac.id/index.php/T I_atma_luhur/article/view/272

Rusdiana, \& Irfan, M. (2014). Rusdiana dan Much. Irfan, Sistem Informasi Manajemen. Pustaka Setia.

Setyanto, E., Rasyidah, N., \& Sulhan, M. (2018). Aplikasi Tik dalam Manajemen Pendidikan Dasar dan Menengah. HIKMAH: Jurnal Pendidikan Islam, 6(2), 298-317. https://ojs.staituankutambusai.ac.id/index. $\mathrm{php} /$ hikmah/article/view/61/0

Sonia, N. R. (2020). Implementasi Sistem Informasi Manajemen Pendidikan (Simdik) dalam Meningkatkan Mutu Pendidikan di Madrasah Aliyah Negeri 2 Ponorogo. Education, 1(1), 94-104. https://doi.org/10.21154/sajiem.v1i1.18

Ulinafiah, D., \& Wiyani, N. A. (2019). Penciptaan Layanan Prima Melalui Penerapan Sistem Informasi Manajemen di 
Perpustakaan IAIN Purwokerto. Re-JIEM

(Research Journal of Islamic Education

Management), 2(2), 223-239.

https://doi.org/10.19105/re-

jiem.v2i2.2663

Wardhani, N. K., \& Aziz, M. T. A. (2018).

Sistem Informasi Manajemen Sumber Daya

Manusia Berbasis Web (Studi Kasus: PT.

Klik Teknologi Indonesia). Jurnal Techno

Nusa Mandiri, 15(2), 145-152.

https://doi.org/10.33480/techno.v15i2.24 